\title{
Alumina Template Assistance in Titania Nanotubes Dye-Sensitized Solar Cell ( $\mathrm{TiO}_{2}$ NT-DSSC) Device Fabrication
}

\author{
Kuang Hsuan Yang' and Chien Chon Chen ${ }^{2}$ \\ ${ }^{1}$ Department of Materials Science and Engineering, Vanung University, Chung-Li 32061, Taiwan \\ ${ }^{2}$ Department of Energy Engineering, National United University, 2 Lienda, Miaoli 36003, Taiwan \\ Correspondence should be addressed to Kuang Hsuan Yang, khy@mail.vnu.edu.tw
}

Received 9 February 2012; Accepted 27 February 2012

Academic Editors: M. Fernández-García and T. Vartanyan

Copyright (C) 2012 K. H. Yang and C. C. Chen. This is an open access article distributed under the Creative Commons Attribution License, which permits unrestricted use, distribution, and reproduction in any medium, provided the original work is properly cited.

\begin{abstract}
In our previous works, we have made alumina template films and used it for nanowire, nanowhisk, and nanosphere fabrication and molecular aggregation studies. In the present paper, we have combined $\mathrm{Al}_{2} \mathrm{O}_{3}$ template and titania $\left(\mathrm{TiO}_{2}\right) \mathrm{NT}$ fabrication processes to achieve an $\mathrm{Al}_{2} \mathrm{O}_{3} / \mathrm{TiO}_{2} \mathrm{NT}$ dye-sensitized solar cell (DSSC) devices. The DSSC structure includes glass substrate, transparent conductive film of ITO, Pt particles serving as the counter electrode, $\mathrm{Al}_{2} \mathrm{O}_{3} / \mathrm{TiO}_{2} \mathrm{NT}$ film, dye, and ITO serving as the working electrode, and the electrolyte is injected into the counter-working interface. $\mathrm{Al}_{2} \mathrm{O}_{3}$ template was made by anodization and $\mathrm{TiO}{ }_{2}$ NT was made by sol-gel deposition into $\mathrm{Al}_{2} \mathrm{O}_{3}$ template. $\mathrm{Al}_{2} \mathrm{O}_{3}$ template has a light, transparence, large surface, good mechanical strength, and flexibility, making it a candidate material for DSSC electrode template. $\mathrm{TiO}_{2} \mathrm{NT}$ is a semiconductor with an energy gap that matches up very nicely with N3 sensitized dye.
\end{abstract}

\section{Introduction}

Due to increasing energy demands and concerns about global warming, scientists are looking for potential renewable energy sources. Because the sun is the most important inexhaustible and clean energy source, efficiently harvesting solar energy to generate electric power using photovoltaic technology beyond silicon systems has undergone rapid development over the past few years.

Presently there are several technical schemes for solar cell design, including monocrystalline/polycrystalline silicon solar cells, amorphous silicon solar cells, thin film solar cells, and wet type dye-sensitized solar cells (DSSCs). Of these, monocrystalline silicon solar cells currently have the leading position in the market due to their relatively high transformation efficiency (12-20\%). However, since monocrystalline silicon wafers are expensive, manufacturing costs for these cells are high. DSSCs have gradually become more popular due to their lower cost and relatively simple manufacturing process. A DSSC consists of an anode, electrolytic solution, and a cathode. A semiconductor layer is formed on the surface of the anode and photosensitive dyes are absorbed therein.
Since the development of low-cost DSSC technology in 1991 by O'Regan and Grätzel [1], DSSC has been regarded as a promising candidate for next-generation solar cell design [2]. Traditionally, the electron-collecting layer (anode) of a DSSC is composed of randomly packed $\mathrm{TiO}_{2}$ nanoparticles (NPs). With sunlight irradiated from the transparent anode (front illumination), the best photovoltaic power conversion efficiency $(\eta)$ of an NP-DSSC device has reached $\sim 11 \%$ [3$5]$. The great advantage of NP-DSSC is the large surface area of the nanoporous $\mathrm{TiO}_{2}$ films for dye adsorption. However, the trap-limited diffusion for electron transport in NP-DSSC is a limiting factor in achieving higher light-to-electricity conversion efficiency [6]. To improve charge-collection efficiency by promoting faster electron transport and slower charge recombination, several different methods have been established using $\mathrm{TiO}_{2}$ films constructed of oriented onedimensional (1D) nanostructures. For example, the best cell performance of DSSCs based on $1 \mathrm{D} \mathrm{TiO}_{2}$ nanowires (NWs) has reached $\eta=5.0 \%$ under front-side illumination $[7,8]$. Also, $1 \mathrm{D} \mathrm{TiO}_{2}$ nanotubes (NTs) have been synthesized using sol-gel [9] and potentiostatic anodization [10] methods.

NT-DSSCs using the $\mathrm{TiO}_{2}$ NT arrays on Ti foil as working electrodes have three important intrinsic features 


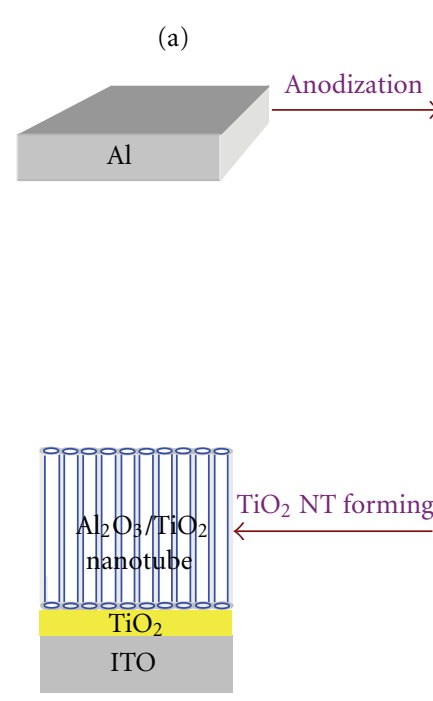

(f) (b)

(c)

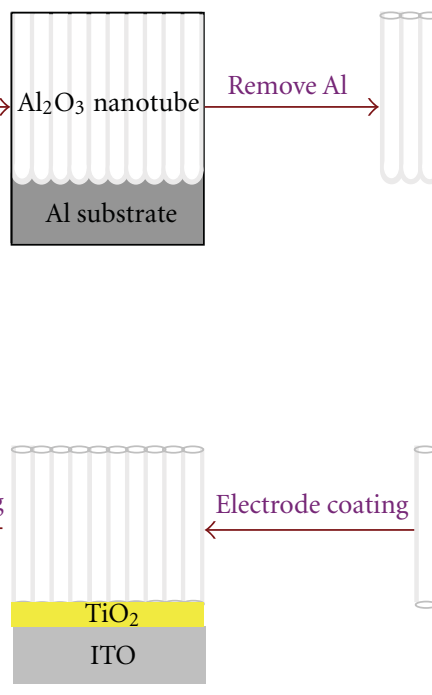

(e)

FIGURE 1: Schematic diagrams of DSSC anode-fabricated processing by used $\mathrm{TiO}_{2} \mathrm{NT}$ and $\mathrm{Al}_{2} \mathrm{O}_{3}$ templates. (a) purify $\mathrm{Al}$ (99.7\%) through anodization forming and (b) $\mathrm{Al}_{2} \mathrm{O}_{3}$ template on the $\mathrm{Al}$ surface, (c) remove $\mathrm{Al}$ substrate by $\mathrm{CuCl}_{2}+\mathrm{H}_{2} \mathrm{O}$ solution, (d) remove barrier layer by $\mathrm{H}_{3} \mathrm{PO}_{4}$ solution, (e) sputter $\mathrm{TiO}_{2}$ as under layer and ITO as conducted layer forming conductor electrode, (f) deposit TiO $\mathrm{T}_{2}$ inside $\mathrm{Al}_{2} \mathrm{O}_{3}$ template by $\mathrm{TiF}_{4}$ solution to form DSSC anode.

that allow it to outperform the conventional NP-DSSCs. First, the charge-collection efficiencies of NT films have been proved to be much better than those of NP films because of the 1D nature of the former, with a much slower charge recombination rate $[11,12]$. This intrinsic advantage of NTDSSC promotes its cell performance significantly with tube lengths up to $20 \mu \mathrm{m}$, as reported by Grimes and coworkers [13]. Second, the light-harvesting efficiencies of the NT films are much better than those of the NP films because of the stronger light scattering effect of the former. In fact, for a traditional high-efficiency NP-DSSC, adding an additional $\mathrm{TiO}_{2}$ layer with a larger particle size $(\sim 400 \mathrm{~nm})$ is required to increase the light scattering effect, while this effect is a natural property for an NT-DSSC. Third, the anode fabrication of NT-DSSCs is much simpler and more cost-effective than that of NP-DSSCs. Direct anodization of a Ti foil in a onestep process produces the blank $\mathrm{TiO}_{2}$ film ready to make a working electrode in NT-DSSCs, whereas making the blank $\mathrm{TiO}_{2}$ film in NP-DSSCs requires a multiple coating process for at least two layers of $\mathrm{TiO}_{2}$ NPs coated on a relatively expensive transparent conducting oxide (TCO) substrate.

The use of a longer NT in the device causes certain problems. For example, cracking and a compact layer are produced on the surface of the NT films, and the longer the $\mathrm{TiO}_{2}$ NT, the weaker adhesion of NT on the Ti substrate. To reduce the cracks and eliminate the compact layer for a longer $\mathrm{TiO}_{2}$ NT, Grimes [13] and coworkers used $0.1 \mathrm{M}$ hydrochloric acid $(\mathrm{HCl})$ to dissolve the compact layer; Zhu and coworkers [12] used a supercritical $\mathrm{CO}_{2}$ drying technique to produce bundle-free and crack-free NT films. Chen et al. [14] used $\mathrm{Al}_{2} \mathrm{O}_{3}$ microparticles with the aid of ultrasonic vibration to remove the compact layer and to avoid crack formation. The mechanical strength of $\mathrm{TiO}_{2} \mathrm{NT}$ is not great, so a longer tube can crack easily, leading to the peeling off of the NT film from the Ti substrate. Therefore, we propose to use anodic aluminum oxide $\left(\mathrm{AAO}\right.$ or $\mathrm{Al}_{2} \mathrm{O}_{3}$ template) as a template, followed by deposition of $\mathrm{TiO}_{2} \mathrm{NT}$ inside AAO to make a working electrode for NT-DSSC. AAO is fabricated by anodization process, and then the chemical etching method is used to achieve AAO nanotubes with open pores on both sides. Because AAO has better mechanical properties than $\mathrm{TiO}_{2} \mathrm{NT}$, the AAO morphology can also be controlled more easily than can that of $\mathrm{TiO}_{2}$ NT. For example, AAO pore diameter, length, and pore density can be controlled in the range of $10-500 \mathrm{~nm}, 0.1-200 \mu \mathrm{m}$, and $10^{8}-10^{12}$ tubes $\mathrm{cm}^{-2}$, respectively.

According to reports from Imai [15-17], when $\mathrm{TiF}_{4}$ solutions have a pH below 1.0 or a $\mathrm{TiF}_{4}$ concentration below $0.03 \mathrm{M}$, neither precipitation nor film formation was observed. A large amount of precipitate was rapidly formed, and film was not deposited, on substrates above $\mathrm{pH}$ 3.1. Therefore, the concentration of $\mathrm{TiF}_{4}$ should be controlled above $0.03 \mathrm{M}$, and the $\mathrm{pH}$ value should be controlled between 1 and 3 so that $\mathrm{TiO}_{2}$ nanoparticles can present and be deposited on the substrate. For example, Chen et al. [18] used $\mathrm{pH} 1.8,0.04 \mathrm{M} \mathrm{TiF}_{4}$ solution at $60^{\circ} \mathrm{C}$ for deposition on a $\mathrm{TiO}_{2} \mathrm{NT}$ in $\mathrm{AAO}$ membrane.

In our previous work, we have made AAO film [19] and used this templates for the fabrication of nanowires [20-23], nanowhisks [24], and nanospheres [25-29] and the study of molecular aggregation $[30,31]$. We have also made $\mathrm{TiO}_{2}$ NT film [32-36] and used it for DSSC device fabrication, allowing the photovoltaic power conversion efficiency to reach $\eta \sim 7 \%[14,37]$. In this paper, we have combined our previous $\mathrm{Al}_{2} \mathrm{O}_{3}$ template, $\mathrm{TiO}_{2} \mathrm{NT}$, and DSSC fabrication technologies to achieve an $\mathrm{Al}_{2} \mathrm{O}_{3} / \mathrm{TiO}_{2}$ NT-DSSC device. 


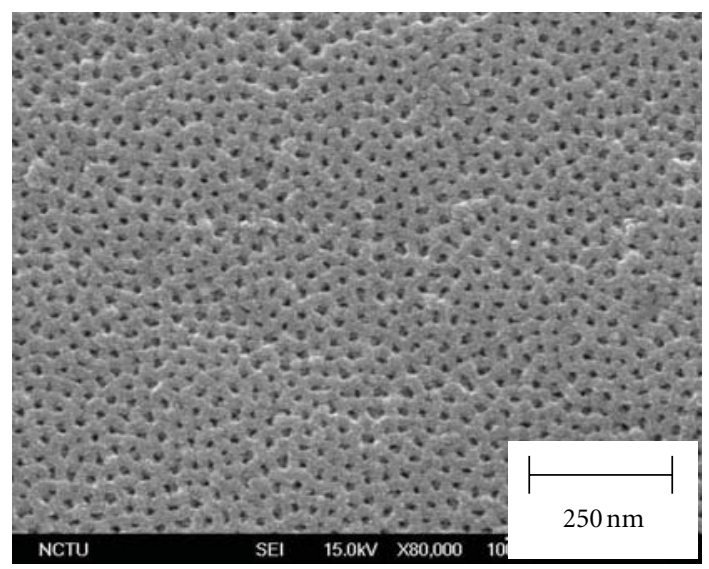

(a)

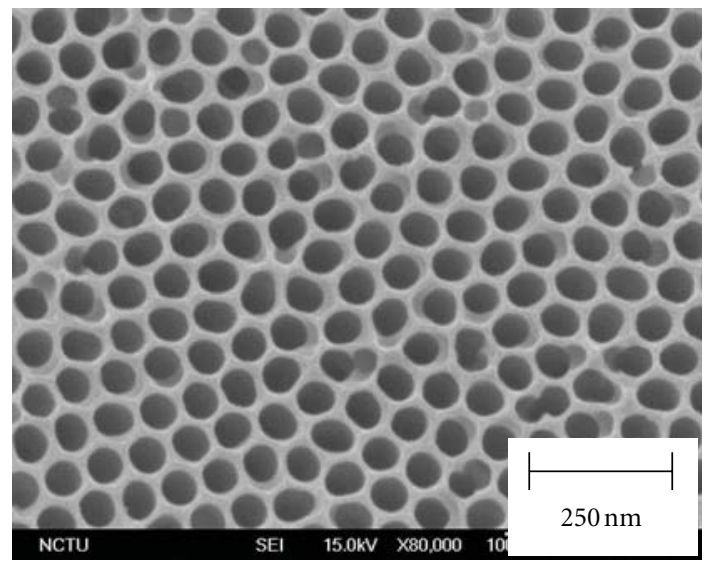

(c)

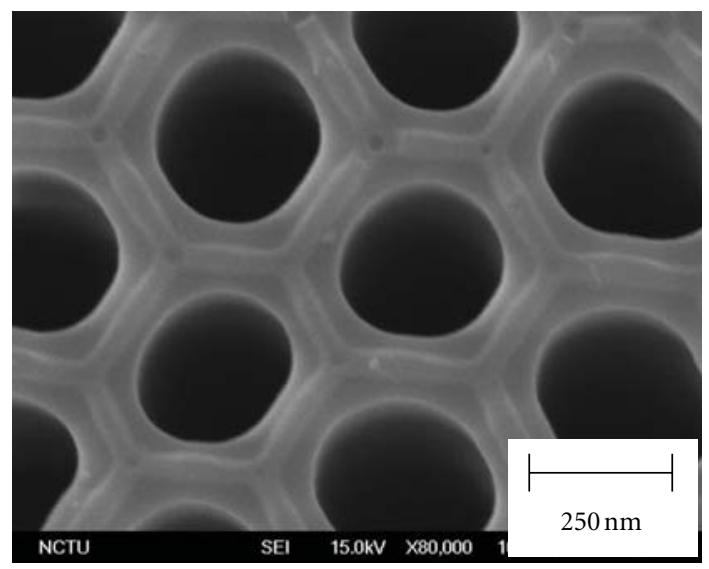

(e)

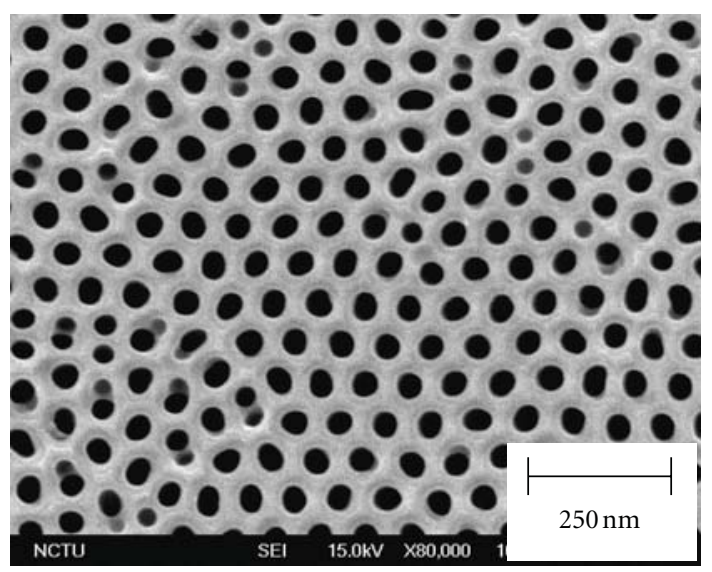

(b)

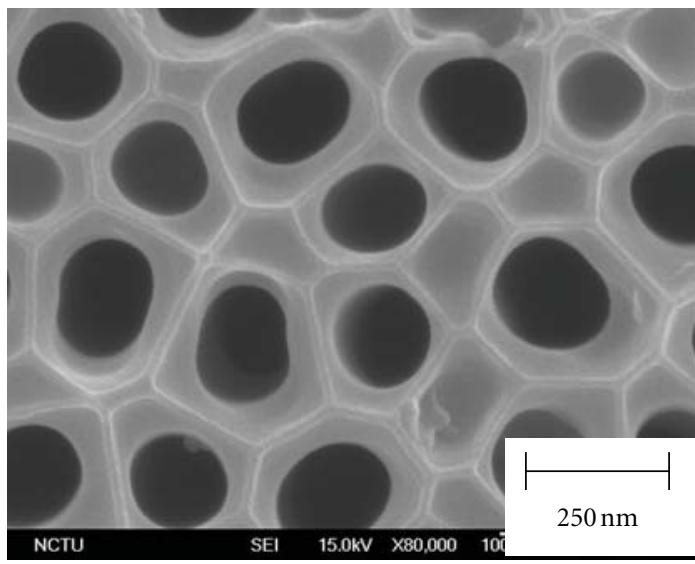

(d)

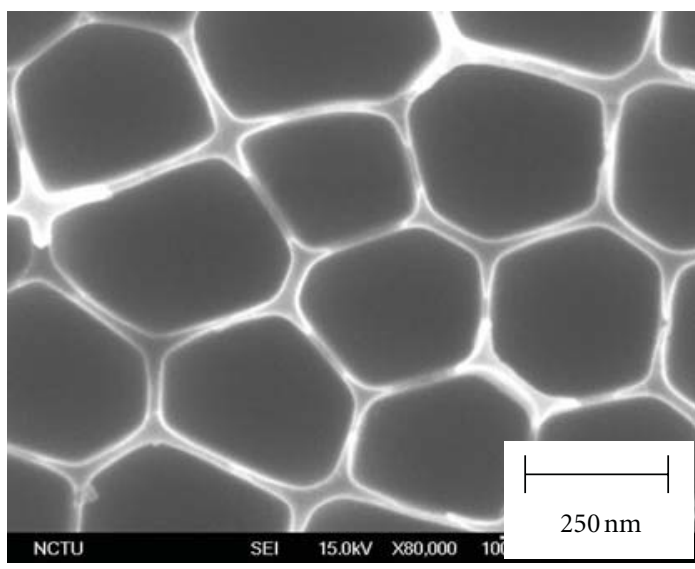

(f)

Figure 2: SEM images of $\mathrm{Al}_{2} \mathrm{O}_{3}$ template film with various pore sizes of (a) $10 \mathrm{~nm}$, (b) $50 \mathrm{~nm}$, (c) $90 \mathrm{~nm}$, (d) $300 \mathrm{~nm}$, (e) $400 \mathrm{~nm}$, and (f) $500 \mathrm{~nm}$.

\section{Experimental}

2.1. $\mathrm{Al}_{2} \mathrm{O}_{3}$ Template Fabrication. $\mathrm{Al}_{2} \mathrm{O}_{3}$ templates with a pore size of 10 to $500 \mathrm{~nm}$ were generated by anodizing a commercial aluminum ( $\mathrm{Al}$ ) substrate $(99.7 \%)$ in acid solutions of sulfuric acid $\left(\mathrm{H}_{2} \mathrm{SO}_{4}\right)$, oxalic acid $(\mathrm{COOH})_{2}$, or phosphoric acid $\left(\mathrm{H}_{3} \mathrm{PO}_{4}\right)$. The $\mathrm{Al}$ substrate was first ground to no. 1000 by $\mathrm{SiC}$ waterproof paper and then annealed in an air furnace at $550^{\circ} \mathrm{C}$ for $1 \mathrm{hr}$. The sample was then electropolished in a bath consisting of $15 \mathrm{vol} . \%$ perchloric acid $\left(\mathrm{HClO}_{4}, 70 \%\right)$, 70 vol.\% ethanol $\left(\mathrm{C}_{2} \mathrm{H}_{6} \mathrm{O}, 99.5 \%\right)$, and 15 vol.\% monobutyl ether $\left(\left(\mathrm{CH}_{3}\left(\mathrm{CH}_{2}\right)_{3} \mathrm{OCH}_{2} \mathrm{CH}_{2} \mathrm{OH}\right), 85 \%\right)$ with a charge of 42 volts (DC) applied for $10 \mathrm{~min}$, used platinum plate as a counter. 


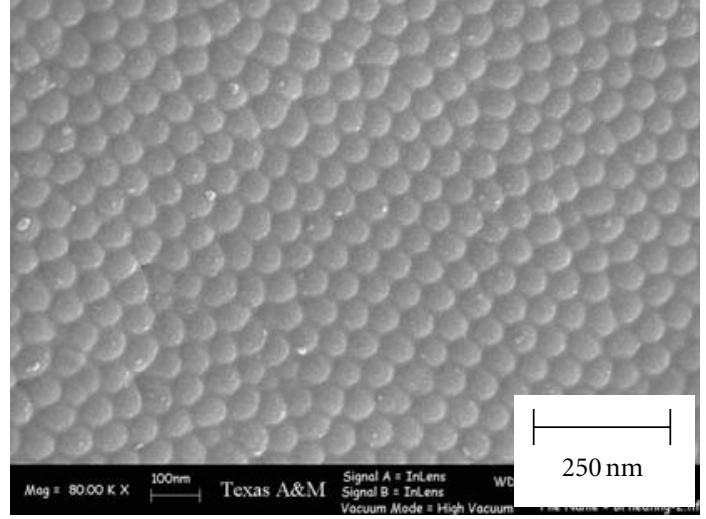

(a)

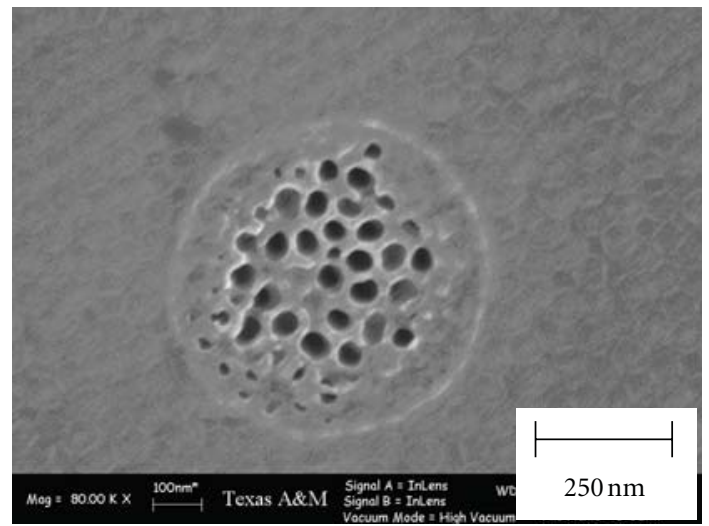

(c)

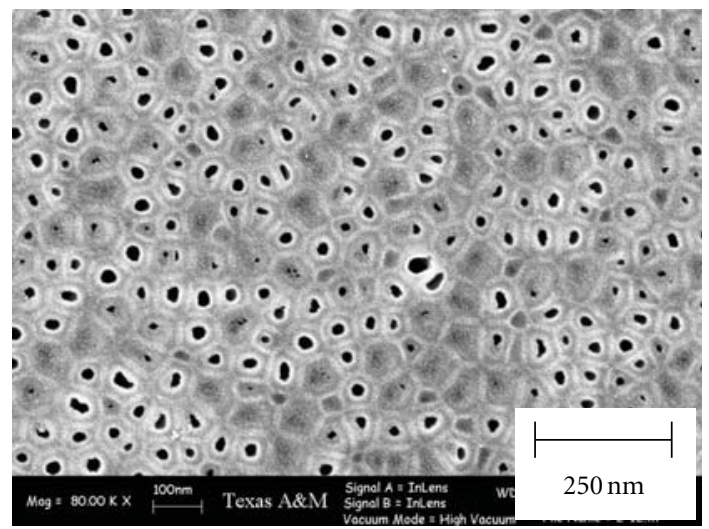

(e)

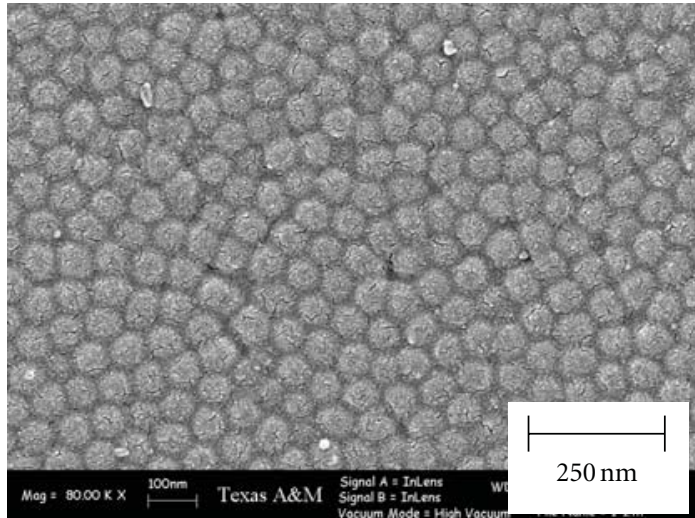

(b)

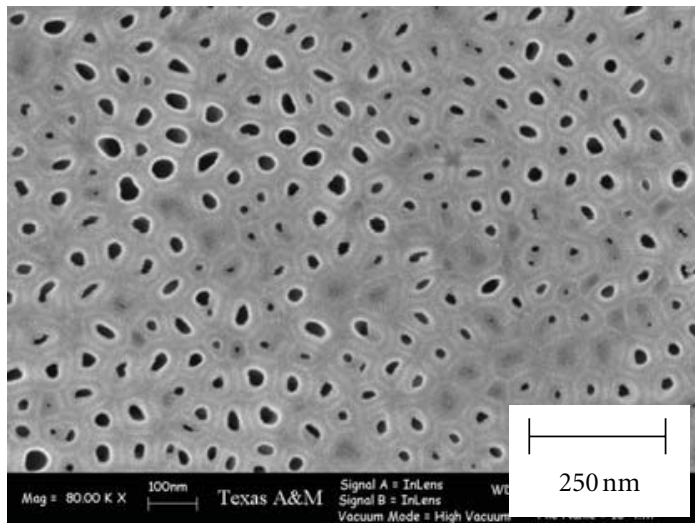

(d)

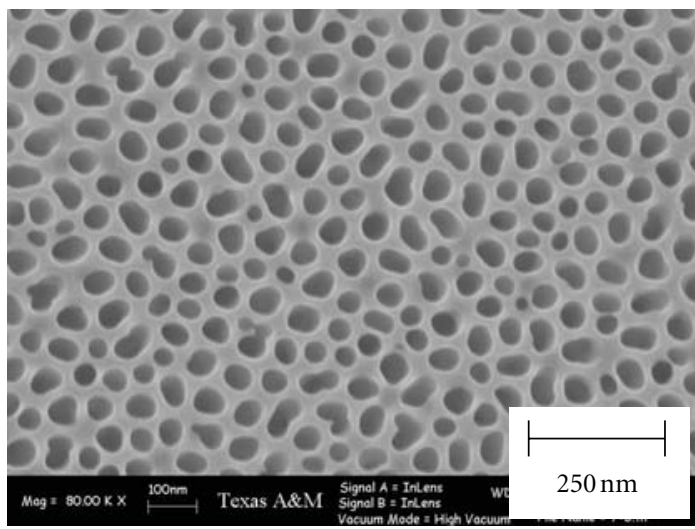

(f)

FIgURE 3: SEM images of bottom $\mathrm{Al}_{2} \mathrm{O}_{3}$ template film. (a) A compact $\mathrm{Al}_{2} \mathrm{O}_{3}$ barrier layer cover on $\mathrm{Al}_{2} \mathrm{O}_{3}$ template bottom, (b) dissolving barrier by $5 \% \mathrm{H}_{3} \mathrm{PO}_{4}$ solution at $25^{\circ} \mathrm{C}$ for 10 min during which grain boundaries were etched, (c) 30 min during which partial barrier layer was dissolved, (d) 50 min during which barrier layer has become thin film, (e) 70 min during which most of barrier layer was removed, and (f) 90 min during which barrier layer was removed, completely.

A $10 \mathrm{~nm}$ pore diameter template was then fabricated by anodizing the polished-Al substrate at $18 \mathrm{~V}$ in 10 vol.\% $\mathrm{H}_{2} \mathrm{SO}_{4}$ at $15^{\circ} \mathrm{C}$ for $20 \mathrm{~min}$, which was the first anodization. In order to obtain an orderly pattern on the substrate for the second anodization, the first anodization film was removed in 1.8 wt. $\%$ chromic acid $\left(\mathrm{CrO}_{3}\right)+6$ vol. $\% \mathrm{H}_{3} \mathrm{PO}_{4}$ solution at $60^{\circ} \mathrm{C}$ for $40 \mathrm{~min}$. The resulting substrate, with a regular pattern on the surface, was used for the second anodization for several hours to form an AAO film with various thicknesses. After $\mathrm{Al}_{2} \mathrm{O}_{3}$ template formed, the $\mathrm{Al}$ substrate was removed by placing the sample in saturated copper chloride $\left(\mathrm{CuCl}_{2}\right)+10$ vol. $\%$ hydrochloric acid $(\mathrm{HCl})$ for $30 \mathrm{~min}$. Finally, the sample was put in 5 vol. $\% \mathrm{H}_{3} \mathrm{PO}_{4}$ at $25^{\circ} \mathrm{C}$ for 5 to $20 \mathrm{~min}$. The nanotubes were widened to an ordered array and a good quality $\mathrm{Al}_{2} \mathrm{O}_{3}$ template film with 10 to $50 \mathrm{~nm}$ pore size was formed. Similar to the above process, 


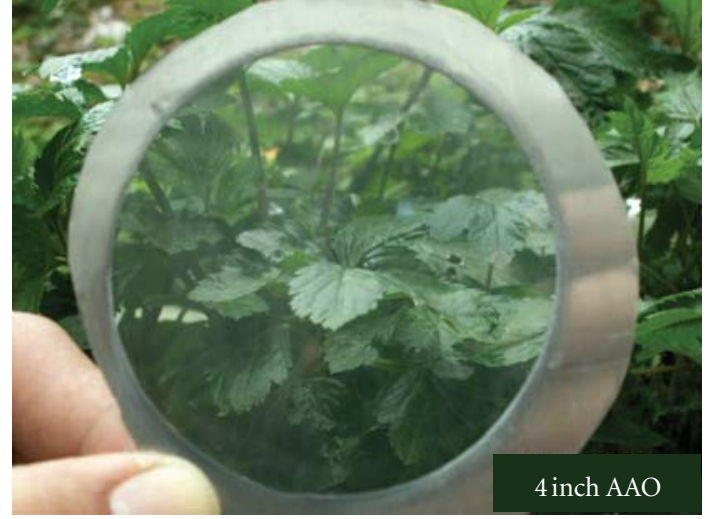

(a)

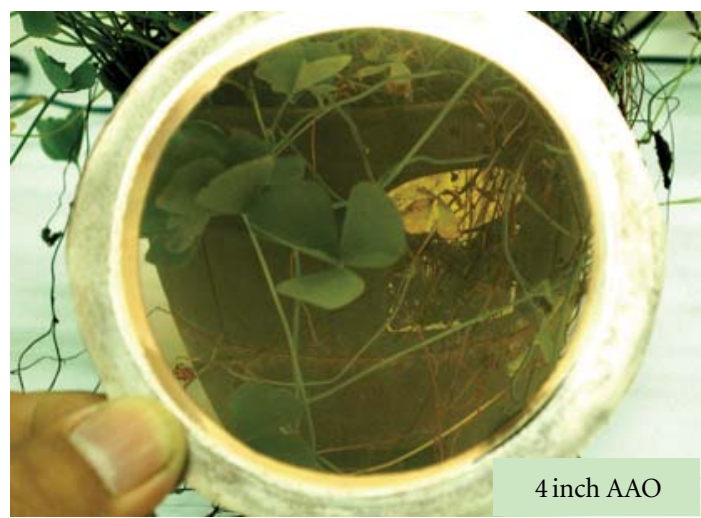

(b)

FIgURE 4: Image of (a) original 4-inch transparent $\mathrm{Al}_{2} \mathrm{O}_{3}$ template film and (b) the color changing to light red after absorption in $\mathrm{N} 3$ sensitized dye.

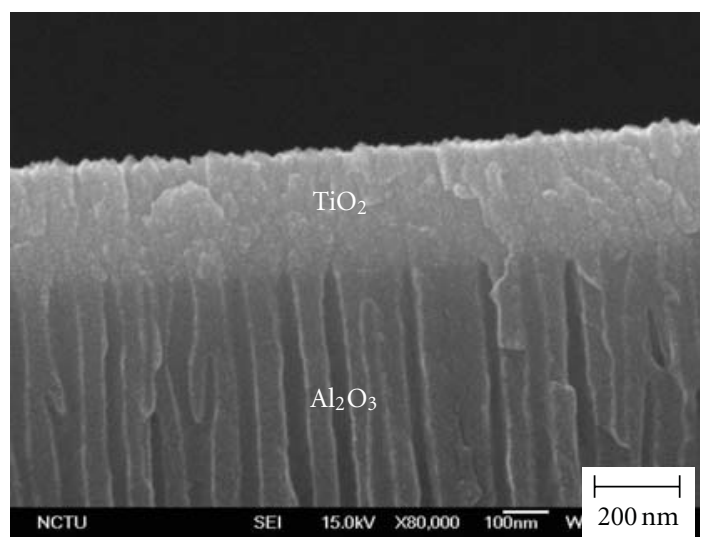

(a)

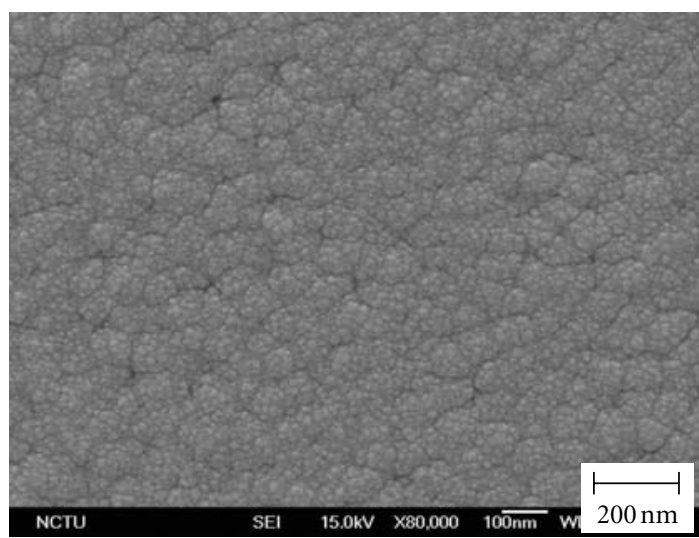

(b)

Figure 5: SEM images of (a) side and (b) top views of $\mathrm{TiO}_{2}$ film on $\mathrm{Al}_{2} \mathrm{O}_{3}$ template surface.

for 40 to $90 \mathrm{~nm}$ pore diameter $\mathrm{Al}_{2} \mathrm{O}_{3}$ template, the electrolyte was 3 vol. $\%(\mathrm{COOH})_{2}$ at $25^{\circ} \mathrm{C}$, and the applied voltage was $40 \mathrm{~V}$. The time of pore widening was 10 to $90 \mathrm{~min}$. For 180 to $500 \mathrm{~nm}$ pore diameter AAO template, the electrolyte was 1 vol. $\% \mathrm{H}_{3} \mathrm{PO}_{4}$ at $0{ }^{\circ} \mathrm{C}$, and the applied voltage was 200 $\mathrm{V}$. The time of pore widening was between 30 to $200 \mathrm{~min}$ $[19,20,25,38,39]$.

2.2. DSSC Device Fabrication. Three key components are essential to construct a sandwich-type DSSC device: (1) a light-harvesting layer of $\mathrm{TiO}_{2} / \mathrm{Al}_{2} \mathrm{O}_{3}$ template film with a $\mathrm{TiO}_{2}$ and ITO coating to serve as a working electrode (anode); (2) a Pt-coated layer deposited on an ITO surface to serve as a counter electrode (cathode); (3) an iodinebased electrolyte filled into the space between the anode and the cathode to serve as a redox couple of the cell. The $\mathrm{TiO}_{2} \mathrm{NT}$ was prepared by immersing $\mathrm{Al}_{2} \mathrm{O}_{3}$ template in $0.02 \mathrm{M}$ titanium fluoride $\left(\mathrm{TiF}_{4}\right)$ solution $(\mathrm{pH}=3)$ at $25^{\circ} \mathrm{C}$ for $120 \mathrm{~min}$, followed by annealing at $450^{\circ} \mathrm{C}$ for $1 \mathrm{hr}$ to obtain anatase $\mathrm{TiO}_{2} \mathrm{NT}$ in the $\mathrm{Al}_{2} \mathrm{O}_{3}$ template. To prevent shortcircuits, on the template bottom was deposited a $300 \mu \mathrm{m}$ compact $\mathrm{TiO}_{2}$ film by a 4 -inch disk of Ti target $(99.9 \%$ purity) sputtered in a gaseous mixture of 90\% Ar and 10\% $\mathrm{O}_{2}$. Sputtering power, gas pressure, substrate temperature, and sputter time were kept constant at $50 \mathrm{~W}, 50 \times 10^{-3}, 50^{\circ} \mathrm{C}$, and $80 \mathrm{~min}$, respectively. Subsequently, a $120 \mu \mathrm{m}$ ITO film was sputtered on $\mathrm{TiO}_{2}$ film to form a conducting electrode by sputter-deposition. An RF magnetron sputtering system was used for ITO preparation. A 4 inch disk of ITO target $(99.9 \%$ purity) was sputtered on the $\mathrm{TiO}_{2}$ film. Sputtering power, gas pressure, substrate temperature, and sputter time were kept constant at $100 \mathrm{~W}, 50 \times 10^{-3}$ torr, $30^{\circ} \mathrm{C}$, and $30 \mathrm{~min}$, respectively. The electrode fabrication process is shown in Figure 1. The electrode $\left(\mathrm{Al}_{2} \mathrm{O}_{3}\right.$ template/TiO $2 \mathrm{NT} / \mathrm{TiO}_{2}$ film/ITO film) was then soaked in ethanol containing $5 \times$ $10^{-4} \mathrm{M} \mathrm{RuL}{ }_{2}(\mathrm{NCS})_{2}$ (N3 dye) for $7 \mathrm{hr}$ to absorb N3 dye, forming the DSSC anode. The micromorphology of $\mathrm{Al}_{2} \mathrm{O}_{3}$ template, $\mathrm{TiO}_{2} \mathrm{NT}, \mathrm{TiO}_{2}$ compact film, and ITO film were determined by scanning electron microscope (SEM, JEOL 6500).

The Pt counter electrodes were prepared by sputter-deposition. A DC magnetron sputtering system was used for the Pt particles. A 4-inch disk of Pt target (99.9\% purity) was sputtered. Sputtering power, gas pressure, substrate 


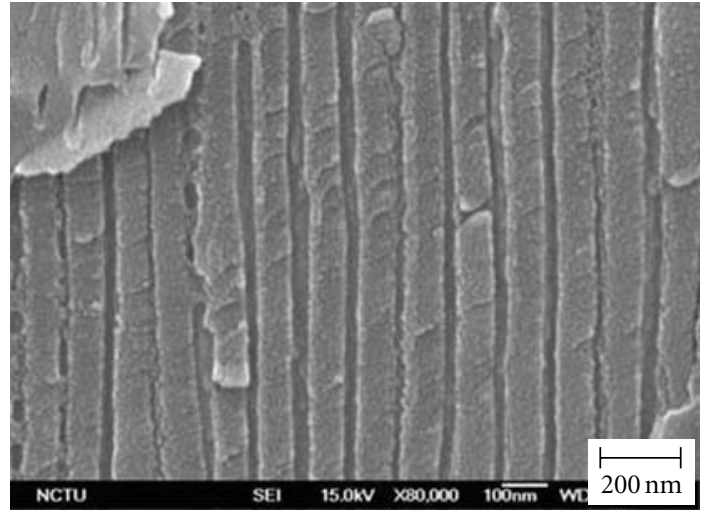

(a)

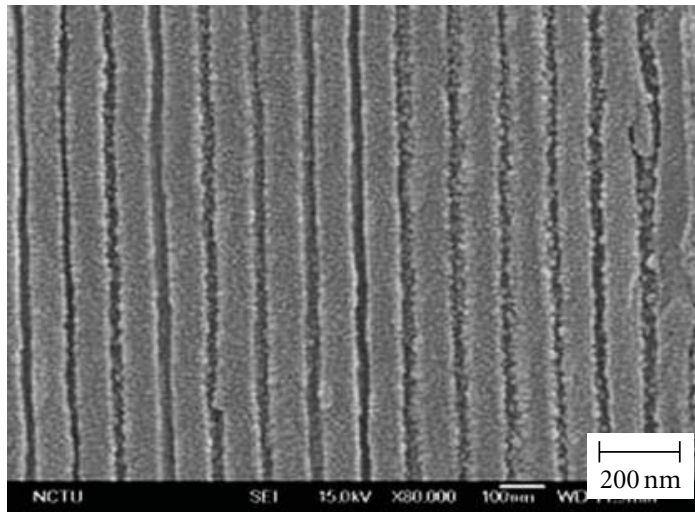

(b)

Figure 6: SEM side-view images of $20 \mathrm{~nm} \mathrm{Al}_{2} \mathrm{O}_{3}$ template (a) before $\mathrm{TiO}_{2} \mathrm{NT}$ inside, and (b) after $\mathrm{TiO}_{2} \mathrm{NT}_{\text {inside. }}$

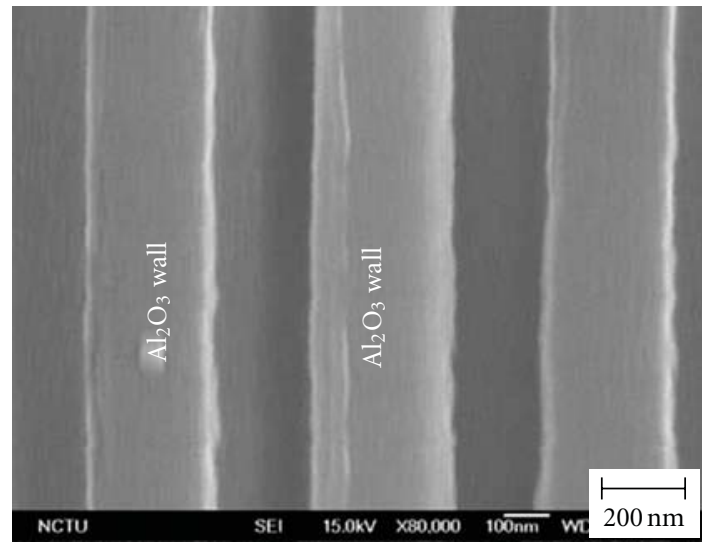

(a)

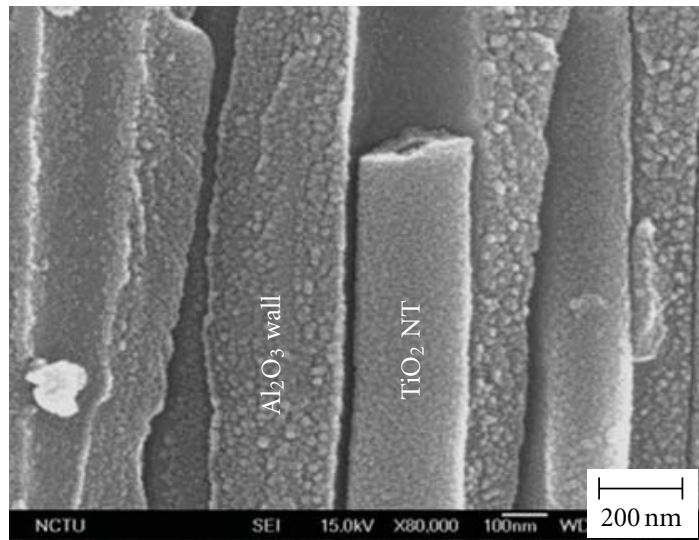

(b)

Figure 7: SEM side-view images of $280 \mathrm{~nm} \mathrm{Al}_{2} \mathrm{O}_{3}$ template (a) before $\mathrm{TiO}_{2} \mathrm{NT}$ inside, and (b) after $\mathrm{TiO}_{2} \mathrm{NT}_{\text {inside. }}$

temperature, and sputter time were kept constant at $10 \mathrm{~W}, 50$ $\times 10^{-3}, 30^{\circ} \mathrm{C}$, and $5 \mathrm{sec}$, respectively.

To prevent short circuits, the cell was assembled with both anode and cathode sealed by using a hot-melt spacer of $25 \mu \mathrm{m}$ thickness; small holes on the corners of the cell were reserved for the entrance of the electrolyte and the exhaust of the air. A thin layer of electrolyte was sucked into the interelectrode space by capillary force, and the holes were sealed by epoxy resin. The typical electrolyte solution consisted of $0.5 \mathrm{M}$ (lithium iodide) LiI and $0.05 \mathrm{M}$ iodine $\left(\mathrm{I}_{2}\right)$ in acetonitrile $\left(\mathrm{CH}_{3} \mathrm{CN}, 99.9 \%\right)$. The photocurrent was produced using an HP model $4140 \mathrm{~B}$ measuring unit. The photocurrent conversion efficiency was tested under an AM $1.5\left(300 \mathrm{~W}, 91160\right.$ Oriel Solar Simulator, $100 \mathrm{mw} \mathrm{cm}^{-2}$ ) on a $0.28 \mathrm{~cm}^{2}$ sample area.

\section{Results and Discussion}

The $\mathrm{Al}_{2} \mathrm{O}_{3}$ template was made by anodization, and the pore size was controlled by electrolyte and the pore-widening period. Figure 2 shows SEM images of $\mathrm{Al}_{2} \mathrm{O}_{3}$ template film with diameter of (a) $10 \mathrm{~nm} \mathrm{Al}_{2} \mathrm{O}_{3}$ template, produced by $10 \mathrm{vol} . \%$
$\mathrm{H}_{2} \mathrm{SO}_{4}$ anodization and 5 vol.\% $\mathrm{H}_{3} \mathrm{PO}_{4}$ pore widening for $5 \mathrm{~min}$; (b) 50 and (c) $90 \mathrm{~nm} \mathrm{Al} \mathrm{O}_{3}$ template produced by 3 wt. $\% \mathrm{C}_{2} \mathrm{H}_{2} \mathrm{O}_{4}$ anodization and 5 vol. $\% \mathrm{H}_{3} \mathrm{PO}_{4}$ pore widening for $30 \mathrm{~min}$ and $90 \mathrm{~min}$; and (d) $300 \mathrm{~nm}$, (e) $400 \mathrm{~nm}$, and (f) $500 \mathrm{~nm} \mathrm{Al}{ }_{2} \mathrm{O}_{3}$ template produced by 1 vol. $\% \mathrm{H}_{3} \mathrm{PO}_{4}$ anodization and 5 vol. $\% \mathrm{H}_{3} \mathrm{PO}_{4}$ pore widening for $90 \mathrm{~min}$, $180 \mathrm{~min}$, and $250 \mathrm{~min}$, respectively. Using the various electrolytes and pore-widening periods, pore sizes of 10 to $500 \mathrm{~nm}$ were obtained.

A barrier layer, which is a dense $\mathrm{Al}_{2} \mathrm{O}_{3}$ film on the bottom of $\mathrm{Al}_{2} \mathrm{O}_{3}$ template, and the electronic insulator film of the barrier resist electron transport. To make the $\mathrm{Al}_{2} \mathrm{O}_{3}$ template as an electrode, the barrier layer should first be removed and then replaced with a coating of conductance film on the template bottom. In our previous results [1821 ], the thickness of the barrier layer was proportional to the anodic applied voltage; the relationship between thickness and voltage can be denoted as $\mathrm{nm} / \mathrm{V}$. For example, the pore sizes of 10 to $50 \mathrm{~nm}, 40$ to $90 \mathrm{~nm}$, and 180 to $500 \mathrm{~nm} \mathrm{Al}_{2} \mathrm{O}_{3}$ templates are anodized by 18,40 , and $200 \mathrm{~V}$, producing barrier layers of 18, 40, and $200 \mathrm{~nm}$, respectively. Therefore, the larger the pore sizes, the thicker the barrier layer and 


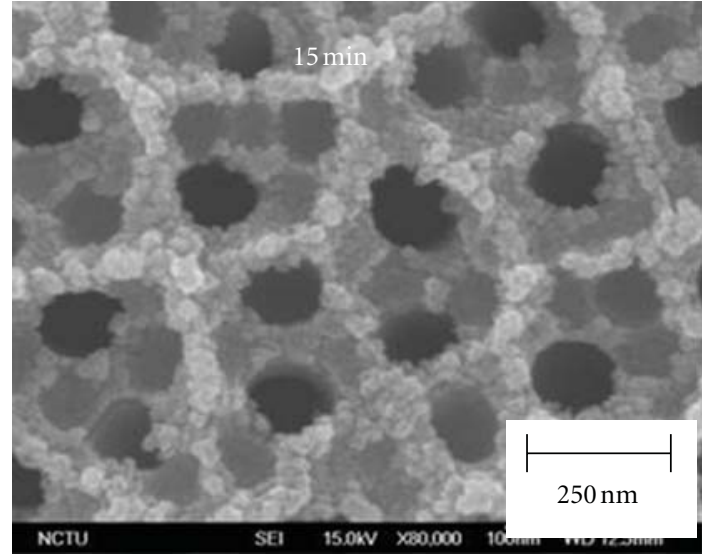

(a)

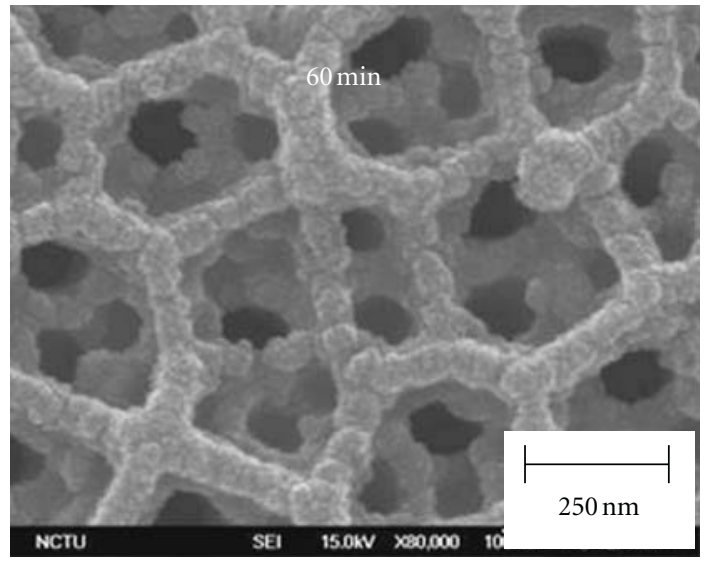

(c)

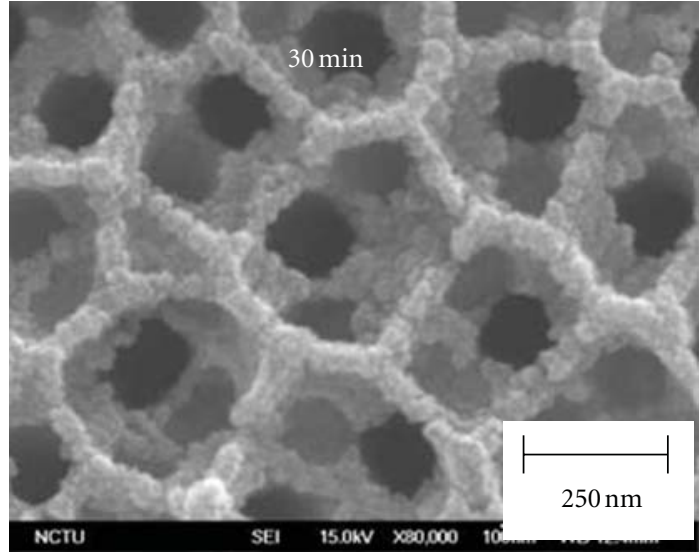

(b)

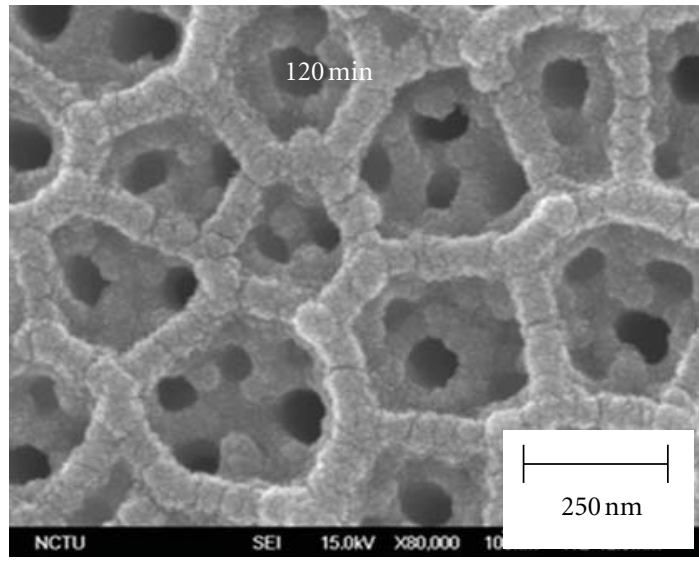

(d)

Figure 8: SEM top view images of $280 \mathrm{~nm} \mathrm{Al}_{2} \mathrm{O}_{3}$ template inside with $\mathrm{TiO}_{2} \mathrm{NT}$ deposited by $0.02 \mathrm{M} \mathrm{TiF}_{4}$ solution $\left(\mathrm{pH}=3\right.$ ) at $25^{\circ} \mathrm{C}$ for $(\mathrm{a})$ $15 \mathrm{~min}$, (b) $30 \mathrm{~min}$, (c) $60 \mathrm{~min}$, and (a) $120 \mathrm{~min}$.

longer the pore-widening period needed. Figure 3 shows SEM images of the bottom of the $\mathrm{Al}_{2} \mathrm{O}_{3}$ template film: (a) a compact $\mathrm{Al}_{2} \mathrm{O}_{3}$ barrier layer covering the bottom of the $\mathrm{Al}_{2} \mathrm{O}_{3}$ template, (b) the barrier dissolved by $5 \% \mathrm{H}_{3} \mathrm{PO}_{4}$ solution at $25^{\circ} \mathrm{C}$ for $10 \mathrm{~min}$ to etch grain boundaries, (c) $30 \mathrm{~min}$, during which the barrier layer was partially dissolved, (d) $50 \mathrm{~min}$, during which the barrier layer became a thin film, (e) $70 \mathrm{~min}$, during which most of barrier layer was removed, and (f) $90 \mathrm{~min}$, after which the barrier layer was removed completely.

The $\mathrm{Al}_{2} \mathrm{O}_{3}$ template had a larger surface area and transparent film. Figure 4 shows images of transparent $\mathrm{Al}_{2} \mathrm{O}_{3}$ template film: (a) original 4-inch transparent $\mathrm{Al}_{2} \mathrm{O}_{3}$ template film and (b) the color changing to light red after N3 sensitized dye was absorbed. As can be seen, an $\mathrm{Al}_{2} \mathrm{O}_{3}$ template structure with discontinuous pores but continuous pore walls gives $\mathrm{Al}_{2} \mathrm{O}_{3}$ template a light, transparent, large surface, and good mechanical strength and flexibility, making it a candidate material for DSSC electrode template. Before adding a coating of a conductive film of ITO on the bottom of the $\mathrm{Al}_{2} \mathrm{O}_{3}$ template, a semiconductor film of $\mathrm{TiO}_{2}$ should first be coated on the bottom of the template. A compact $\mathrm{TiO}_{2}$ film, called an under layer, which serves as an electron transport film (from dye to the conductance electrode) but prevents short circuits (between anode and cathode) is thus formed. Figure 5 shows SEM images of (a) a side view of a $300 \mu \mathrm{m} \mathrm{TiO}_{2}$ film on an $\mathrm{Al}_{2} \mathrm{O}_{3}$ template surface and (b) a top view of compact $\mathrm{TiO}_{2}$ film, which can be an under layer on the DSSC anode, and the rough film surface will enhance the following adherence properties of ITO on $\mathrm{TiO}_{2}$ film.

Figure 6 shows side-view SEM images of $\mathrm{Al}_{2} \mathrm{O}_{3}$ template made with $10 \% \mathrm{H}_{2} \mathrm{SO}_{4}$ solution and pore widening for 8 min with (a) a tube diameter of $20 \mathrm{~nm}$, and (b) $\mathrm{TiO}_{2} \mathrm{NT}$ deposited inside $\mathrm{Al}_{2} \mathrm{O}_{3}$ template. Figure 7 also shows sideview SEM images of $\mathrm{Al}_{2} \mathrm{O}_{3}$ template made by $1 \% \mathrm{H}_{3} \mathrm{PO}_{4}$ solution and pore widening for $80 \mathrm{~min}$ with (a) a tube diameter of $280 \mathrm{~nm}$ and (b) $\mathrm{TiO}_{2} \mathrm{NT}$ deposited inside $\mathrm{Al}_{2} \mathrm{O}_{3}$ template. The thickness of the $\mathrm{TiO}_{2}$ NT pore wall depends on the deposition time. A longer deposition time causes a smaller $\mathrm{TiO}_{2}$ NT pore size, and a $\mathrm{TiO}_{2}$ rod presents after a long deposition time. However, the $\mathrm{TiO}_{2}$ NT surface area is reduced, with increased NT walls. Figure 8 shows SEM top view images of the interiors of $280 \mathrm{~nm} \mathrm{Al}_{2} \mathrm{O}_{3}$ template with $\mathrm{TiO}_{2}$ NT deposited by $0.02 \mathrm{M} \mathrm{TiF}_{4}$ solution $(\mathrm{pH}=3)$ at $25^{\circ} \mathrm{C}$ for (a) $15 \mathrm{~min}$, (b) $30 \mathrm{~min}$, (c) $60 \mathrm{~min}$, and (d) $120 \mathrm{~min}$. $\mathrm{TiO}_{2}$ particles were deposited inside $\mathrm{Al}_{2} \mathrm{O}_{3}$ template and 


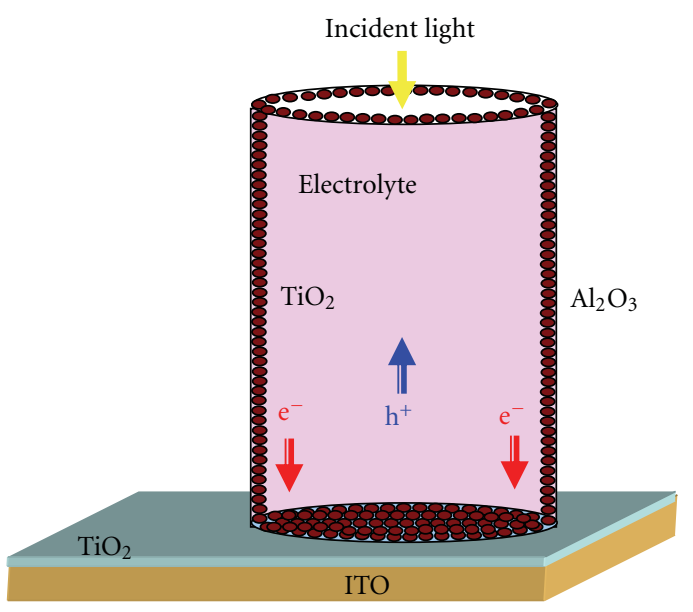

FIgURE 9: Schematic diagram of electron $\left(\mathrm{e}^{-}\right)$and hole $\left(\mathrm{h}^{+}\right)$ transport in the $\mathrm{TiO}_{2}$ NT. Electron transports through $\mathrm{TiO}_{2} \mathrm{NT}$ to $\mathrm{TiO}_{2}$ compact film and conducted electrode, hole transports through electrolyte to counter.

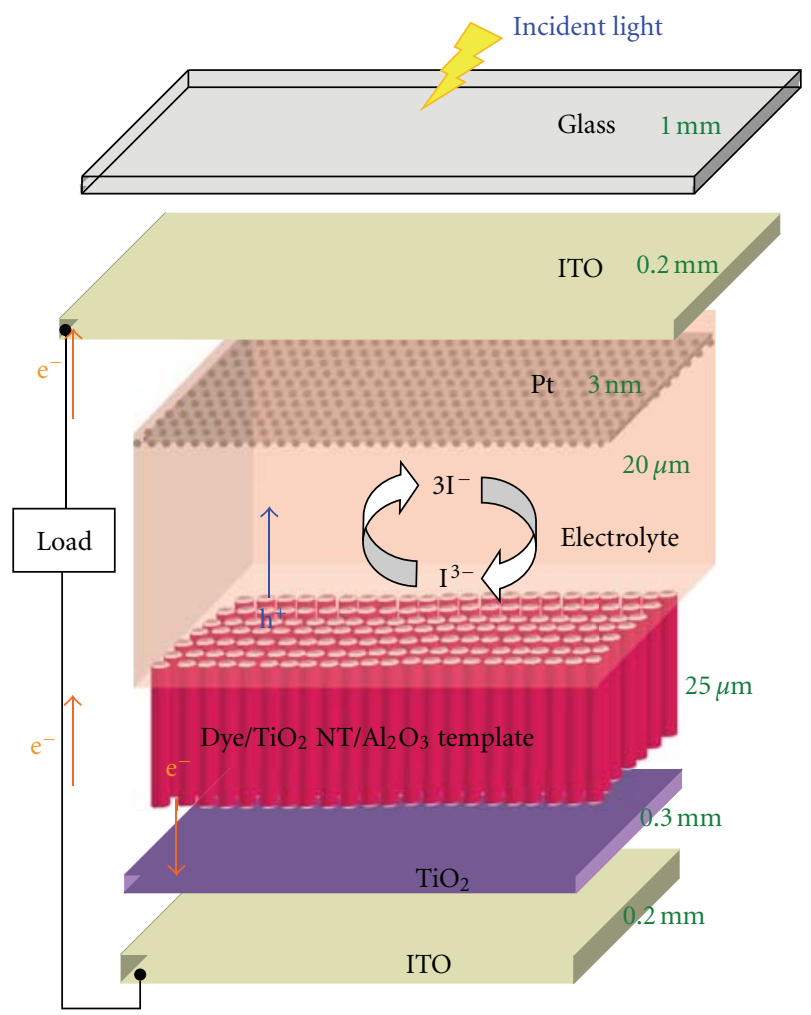

FIGURE 10: Schematic diagram of DSSC device fabricated by $\mathrm{Al}_{2} \mathrm{O}_{3}$ and $\mathrm{TiO}_{2}$ tubes. The structure includes glass, ITO, and Pt particles as counter electrode, $\mathrm{Al}_{2} \mathrm{O}_{3} / \mathrm{TiO}_{2}$ tubes film, dye, and ITO as working electrode, and the electrolyte is injected into counterworking interface.

gradually formed a network film on $\mathrm{Al}_{2} \mathrm{O}_{3}$ template. Figure ?? shows a schematic diagram of electron $\left(\mathrm{e}^{-}\right)$and hole $\left(\mathrm{h}^{+}\right)$ transport in the $\mathrm{TiO}_{2}$ NT. The ITO film serves as a conductive film, and the $\mathrm{TiO}_{2}$ compact film severs as an under layer that resists electrolyte contact with the ITO film. Electrons are transported through the $\mathrm{TiO}_{2} \mathrm{NT}$ to the $\mathrm{TiO}_{2}$ compact

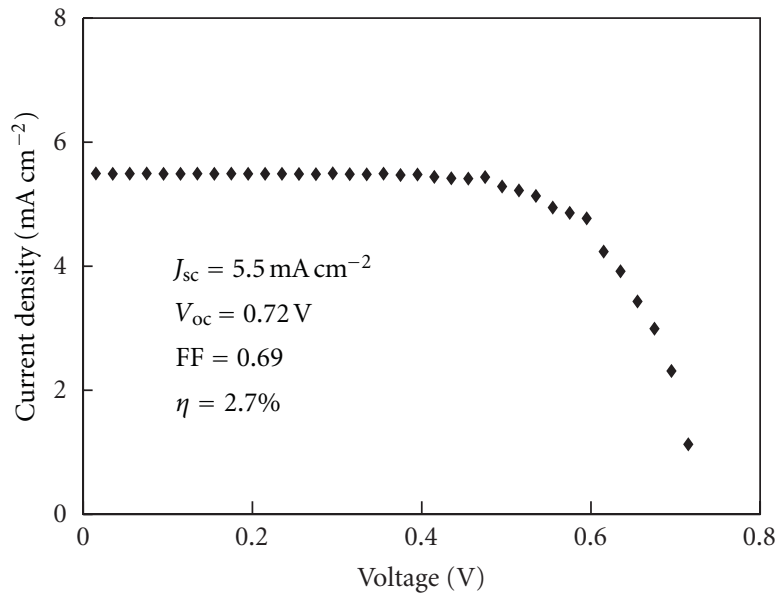

FIGURE 11: Current-voltage characteristics of $\mathrm{Al}_{2} \mathrm{O}_{3}$ and $\mathrm{TiO}_{2}$ tubes DSSC sensitized with N3 dye. The device was measured: $2.7 \%$ conversion efficient, $0.72 \mathrm{~V}$ open circuit voltage, $5.5 \mathrm{~mA} \mathrm{~cm}^{-2}$ short circuit current density, and 0.69 fill factor.

film and then conducting electrode; on the other hand, holes are transported through the electrolyte to counter. In this one-dimensional channel for carrier transportation, the amount of recombination of electron-hole $\left(\mathrm{e}^{-} / \mathrm{h}^{+}\right)$is expected to be reduced. Figure 10 shows a schematic diagram of a DSSC device fabricated with $\mathrm{Al}_{2} \mathrm{O}_{3}$ and $\mathrm{TiO}_{2}$ tubes. The structure includes glass, ITO, Pt particles serving as a counter electrode, and $\mathrm{Al}_{2} \mathrm{O}_{3} / \mathrm{TiO}_{2}$ tubes film, dye, $\mathrm{TiO}_{2}$, and ITO serving as a working electrode. The electrolyte is injected into the counter-working interface. Based on the structure in Figure 10, the current-voltage characteristics of $\mathrm{Al}_{2} \mathrm{O}_{3} / \mathrm{TiO}_{2}$ NT-DSSC with $\mathrm{N} 3$ dye were measured as in Figure 11. The performance of the device was measured as having $2.7 \%$ conversion efficiency, $0.72 \mathrm{~V}$ of open circuit voltage, $5.5 \mathrm{~mA} \mathrm{~cm}^{-2}$ of short circuit current density, and 0.69 of fill factor. An awkward sealing technology with thin film DSSC device may cause short circuit effects between anode and cathode. Also, the device performance had a lower of open circuit voltage fill factor and short current density.

\section{Conclusions}

We propose the use of anodic aluminum oxide as a template followed by deposition of $\mathrm{TiO}_{2} \mathrm{NT}$ inside the template to make a working electrode for flexible NT-DSSC. An alumina template was fabricated by anodization and chemical etching to achieve $\mathrm{Al}_{2} \mathrm{O}_{3}$ nanotubes with open pores on both sides. $\mathrm{Al}_{2} \mathrm{O}_{3}$ template with pore sizes of 10 to $50 \mathrm{~nm}, 40$ to $90 \mathrm{~nm}$, and 180 to $500 \mathrm{~nm}$ was anodized by 18,40 , and $200 \mathrm{~V}$. The thicknesses of the barrier layers were 18, 40, and $200 \mathrm{~nm}$, respectively. $\mathrm{Al}_{2} \mathrm{O}_{3}$ template has better mechanical properties than $\mathrm{TiO}_{2}$ NTs and the $\mathrm{Al}_{2} \mathrm{O}_{3}$ template morphology can also be controlled easily than $\mathrm{TiO}_{2}$ NT. Based on the AAO and $\mathrm{TiO}_{2} \mathrm{NT}$ as an electron transport film, the $\mathrm{Al}_{2} \mathrm{O}_{3} / \mathrm{TiO}_{2}$ NTDSSC device was fabricated, and the performance of the device was measured at $2.7 \%$. 


\section{Acknowledgments}

Part of this study was supported by grants from the National Science Council, Taiwan (NSC-99-2221-E-239-025-). The authors would also like to thank Feng Chia University and National United University for financially supporting this work.

\section{References}

[1] B. O’Regan and M. Grätzel, "A low-cost, high-efficiency solar cell based on dye-sensitized colloidal $\mathrm{TiO}_{2}$ films," Nature, vol. 353, no. 6346, pp. 737-740, 1991.

[2] M. Grätzel, "Photoelectrochemical cells," Nature, vol. 414, no. 6861, pp. 338-344, 2001.

[3] M. K. Nazeeruddin, F. de Angelis, S. Fantacci et al., "Combined experimental and DFT-TDDFT computational study of photoelectrochemical cell ruthenium sensitizers," Journal of the American Chemical Society, vol. 127, no. 48, pp. 16835-16847, 2005.

[4] M. Wei, Y. Konishi, H. Zhou, M. Yanagida, H. Sugihara, and H. Arakawa, "Highly efficient dye-sensitized solar cells composed of mesoporous titanium dioxide," Journal of Materials Chemistry, vol. 16, no. 13, pp. 1287-1293, 2006.

[5] N. Koide, A. Islam, Y. Chiba, and L. Han, "Improvement of efficiency of dye-sensitized solar cells based on analysis of equivalent circuit," Journal of Photochemistry and Photobiology A, vol. 182, no. 3, pp. 296-305, 2006.

[6] M. Law, L. E. Greene, J. C. Johnson, R. Saykally, and P. Yang, "Nanowire dye-sensitized solar cells," Nature Materials, vol. 4, no. 6, pp. 455-459, 2005.

[7] M. Y. Song, D. K. Kim, K. J. Ihn, S. M. Jo, and D. Y. Kim, "Electrospun $\mathrm{TiO}_{2}$ electrodes for dye-sensitized solar cells," Nanotechnology, vol. 15, no. 12, pp. 1861-1865, 2004.

[8] K. Y. Cheung, C. T. Yip, A. B. Djurišić, Y. H. Leung, and W. K. Chan, "Long K-doped titania and titanate nanowires on ti foil and fluorine-doped tin oxide/quartz substrates for solarcell applications," Advanced Functional Materials, vol. 17, no. 4, pp. 555-562, 2007.

[9] G. K. Mor, K. Shankar, M. Paulose, O. K. Varghese, and C. A. Grimes, "Use of highly-ordered $\mathrm{TiO}_{2}$ nanotube arrays in dyesensitized solar cells," Nano Letters, vol. 6, no. 2, pp. 215-218, 2006.

[10] Y. Chiba, A. Islam, Y. Watanabe, R. Komiya, N. Koide, and L. Han, "Dye-sensitized solar cells with conversion efficiency of 11.1\%," Japanese Journal of Applied Physics II, vol. 45, no. 2428, pp. L638-L640, 2006.

[11] J. R. Jennings, A. Ghicov, L. M. Peter, P. Schmuki, and A. B. Walker, "Dye-sensitized solar cells based on oriented $\mathrm{TiO}_{2}$ nanotube arrays: transport, trapping, and transfer of electrons," Journal of the American Chemical Society, vol. 130, no. 40, pp. 13364-13372, 2008.

[12] K. Zhu, N. R. Neale, A. Miedaner, and A. J. Frank, "Enhanced charge-collection efficiencies and light scattering in dye-sensitized solar cells using oriented $\mathrm{TiO}_{2}$ nanotubes arrays," Nano Letters, vol. 7, no. 1, pp. 69-74, 2007.

[13] K. Shankar, G. K. Mor, H. E. Prakasam et al., "Highly-ordered $\mathrm{TiO}_{2}$ nanotube arrays up to $220 \mu \mathrm{m}$ in length: use in water photoelectrolysis and dye-sensitized solar cells," Nanotechnology, vol. 18, no. 6, Article ID 065707, 2007.

[14] C. C. Chen, H. W. Chung, C. H. Chen et al., "Fabrication and characterization of anodic titanium oxide nanotube arrays of controlled length for highly efficient dye-sensitized solar cells," Journal of Physical Chemistry C, vol. 112, no. 48, pp. 1915119157, 2008.

[15] H. Imai, Y. Takei, K. Shimizu, M. Matsuda, and H. Hirashima, "Direct preparation of anatase $\mathrm{TiO}_{2}$ nanotubes in porous alumina membranes," Journal of Materials Chemistry, vol. 9, no. 12, pp. 2971-2972, 1999.

[16] H. Imai, M. Matsuta, K. Shimizu, H. Hirashima, and N. Negishi, "Preparation of $\mathrm{TiO}_{2}$ fibers with well-organized structures," Journal of Materials Chemistry, vol. 10, no. 9, pp. 20052006, 2000.

[17] K. Shimizu, H. Imai, H. Hirashima, and K. Tsukuma, "Lowtemperature synthesis of anatase thin films on glass and organic substrates by direct deposition from aqueous solutions," Thin Solid Films, vol. 351, no. 1-2, pp. 220-224, 1999.

[18] Y. Chen, J. C. Crittenden, S. Hackney, L. Sutter, and D. W. Hand, "Preparation of a novel $\mathrm{TiO}_{2}$-based p-n junction nanotube photocatalyst," Environmental Science and Technology, vol. 39, no. 5, pp. 1201-1208, 2005.

[19] C. C. Chen, J. H. Chen, and C. G. Chao, "Post-treatment method of producing ordered array of anodic aluminum oxide using general purity commercial (99.7\%) aluminum," Japanese Journal of Applied Physics, vol. 44, no. 3, pp. 15291533, 2005.

[20] G. Shi, J. Liang, G. Chen, and S. Du, "Comparison of tensile properties between $\mathrm{NiCoCrAl} / \mathrm{YSZ}$ microlaminates and the monolithic NiCoCrAl foil fabricated by EB-PVD," Materials Letters, vol. 63, no. 20, pp. 1665-1667, 2009.

[21] S. H. Chen, C. C. Chen, and C. G. Chao, "Novel morphology and solidification behavior of eutectic bismuth-tin (Bi-Sn) nanowires," Journal of Alloys and Compounds, vol. 481, no. 1-2, pp. 270-273, 2009.

[22] J. S. Lin, C. C. Chen, E. W. G. Diau, and T. F. Liu, "Fabrication and characterization of eutectic gold-silicon ( $\mathrm{Au}-\mathrm{Si}$ ) nanowires," Journal of Materials Processing Technology, vol. 206, no. 1-3, pp. 425-430, 2008.

[23] C. C. Chen, Y. Bisrat, Z. P. Luo, R. E. Schaak, C. G. Chao, and D. C. Lagoudas, "Fabrication of single-crystal tin nanowires by hydraulic pressure injection," Nanotechnology, vol. 17, no. 2, pp. 367-374, 2006.

[24] W. C. Say and C. C. Chen, "Formation of tin whiskers and spheres on anodic aluminum oxide template," Japanese Journal of Applied Physics, vol. 46, no. 11, pp. 7577-7580, 2007.

[25] C. G. Kuo and C. C. Chen, "Technique for self-assembly of tin nano-particles on anodic aluminum oxide (AAO) templates," Materials Transactions, vol. 50, no. 5, pp. 1102-1104, 2009.

[26] C. G. Kuo, C. C. Chen, S. J. Hsieh, and W. C. Say, "Fabrication of bismuth nanoballs using thermal oil reflow," Journal of the Ceramic Society of Japan, vol. 116, no. 1359, pp. 1193-1198, 2008.

[27] W. C. Say and C. C. Chen, "An efficient technique for the fabrication of nano-size particles of lead-bismuth alloy," Journal of the Ceramic Society of Japan, vol. 116, no. 1350, pp. 288290, 2008.

[28] C. C. Chen, C. G. Kuo, and C. G. Chao, "Template assisted fabrication of tin nanospheres by thermal expansion and rapid solidification process," Japanese Journal of Applied Physics, vol. 44, no. 3, pp. 1524-1528, 2005.

[29] C. C. Chen, C. G. Kuo, J. H. Chen, and C. G. Chao, "Nanoparticles of $\mathrm{Pb}$-Bi eutectic nucleation and growth on alumina template," Japanese Journal of Applied Physics, vol. 43, no. 12, pp. 8354-8359, 2004.

[30] J. S. Lin, Y. C. Chen, C. C. Chen, L. Y. Luo, W. G. Diau, and T. F. Liu, "Fluorescence dynamics of zinc protoporphyrin in 
solution and inside anodized aluminum oxide (AAO) nanochannel arrays," Journal of the Chinese Chemical Society, vol. 53, no. 6, pp. 1405-1412, 2006.

[31] J. S. Lin, Y. C. Chen, C. C. Chen, W. G. Diau, and T. F. Liu, "Aggregation of zinc protoporphyrin in anodized aluminum oxide (AAO) nanoporous environments," Journal of the Chinese Chemical Society, vol. 53, no. 1, pp. 201-208, 2006.

[32] C. C. Chen, W. C. Say, S. J. Hsieh, and E. W. G. Diau, "A mechanism for the formation of annealed compact oxide layers at the interface between anodic titania nanotube arrays and Ti foil," Applied Physics A, vol. 95, no. 3, pp. 889-898, 2009.

[33] W. C. Say, C. C. Chen, and Y. H. Shiu, "Monitoring the effects of growing titania nanotubes on titanium substrate by electrochemical impedance spectroscopy measurement," Japanese Journal of Applied Physics, vol. 48, no. 3, Article ID 035004, 2009.

[34] C. C. Chen, J. S. Lin, W. G. Diau, and T. F. Liu, "Self-cleaning characteristics on a thin-film surface with nanotube arrays of anodic titanium oxide," Applied Physics A, vol. 92, no. 3, pp. 615-620, 2008.

[35] C. C. Chen, J. H. Chen, C. G. Chao, and W. C. Say, "Electrochemical characteristics of surface of titanium formed by electrolytic polishing and anodizing," Journal of Materials Science, vol. 40, no. 15, pp. 4053-4059, 2005.

[36] C. C. Chen and S. J. Hsieh, "Evaluation of fluorine ion concentration in titanium oxide nanotube $\left(\mathrm{TiO}_{2} \mathrm{NT}\right)$ anodization process," Journal of The Electrochemical Society, vol. 156, pp. K125-K130, 2010.

[37] C. C. Chen, W. D. Jehng, L. L. Li, and E. W. G. Diau, "Enhanced efficiency of dye-sensitized solar cells using anodic titanium oxide nanotube arrays," Journal of the Electrochemical Society, vol. 156, no. 9, pp. C304-C312, 2009.

[38] H. Masuda, H. Yamada, M. Satoh, H. Asoh, M. Nakao, and T. Tamamura, "Highly ordered nanochannel-array architecture in anodic alumina," Applied Physics Letters, vol. 71, no. 19, pp. 2770-2772, 1997.

[39] K. T. Sunil and C. C. Hsueh, "Nanoscale pore formation dynamics during aluminum anodization," Chaos, vol. 12, no. 1, pp. 240-251, 2002. 

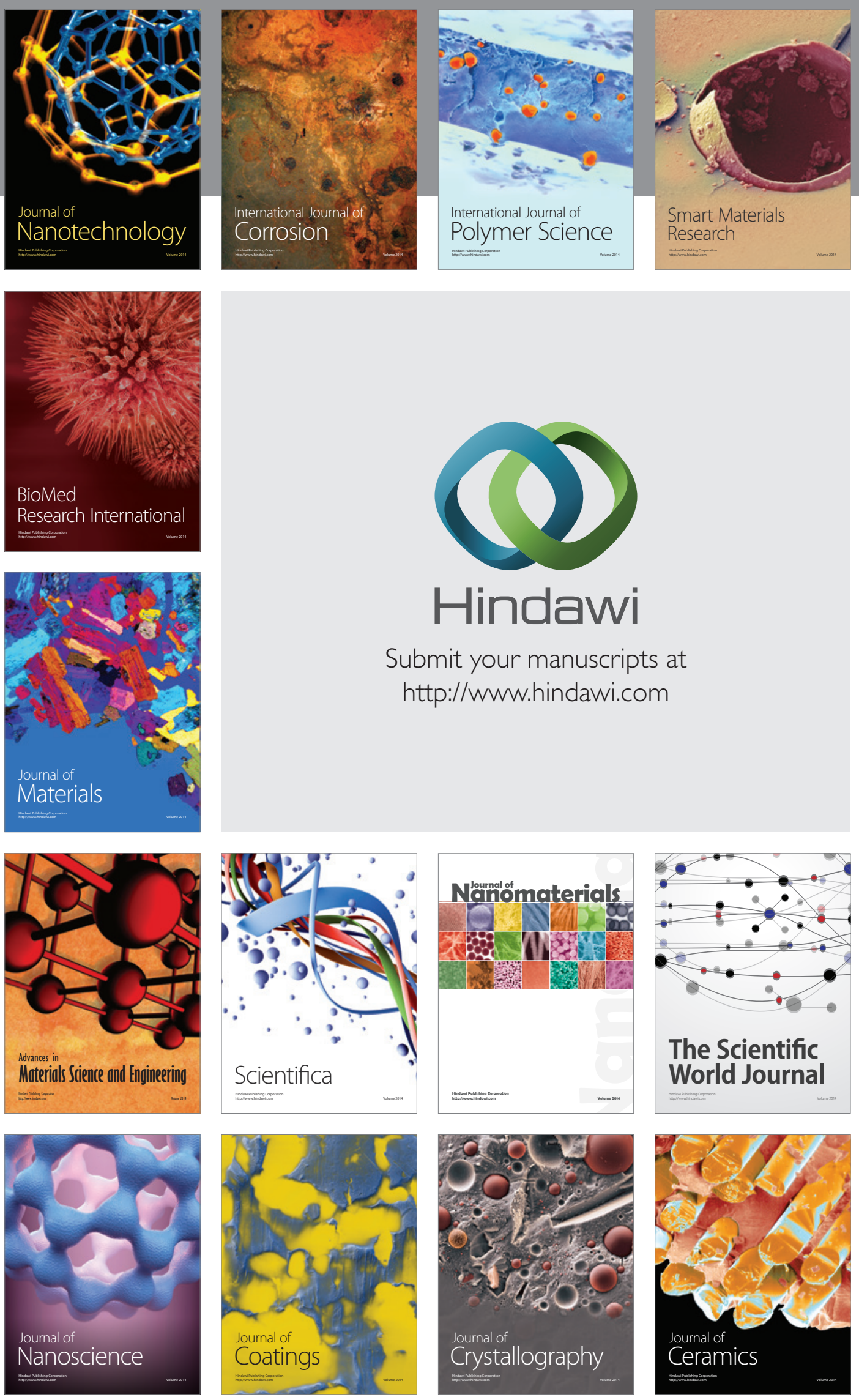

The Scientific World Journal

Submit your manuscripts at

http://www.hindawi.com

\section{World Journal}

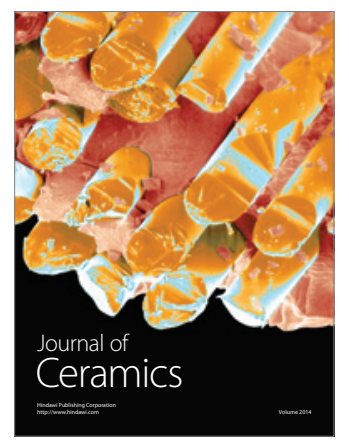

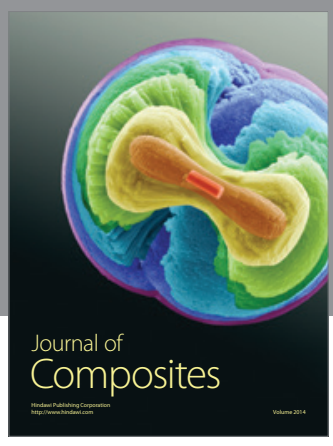
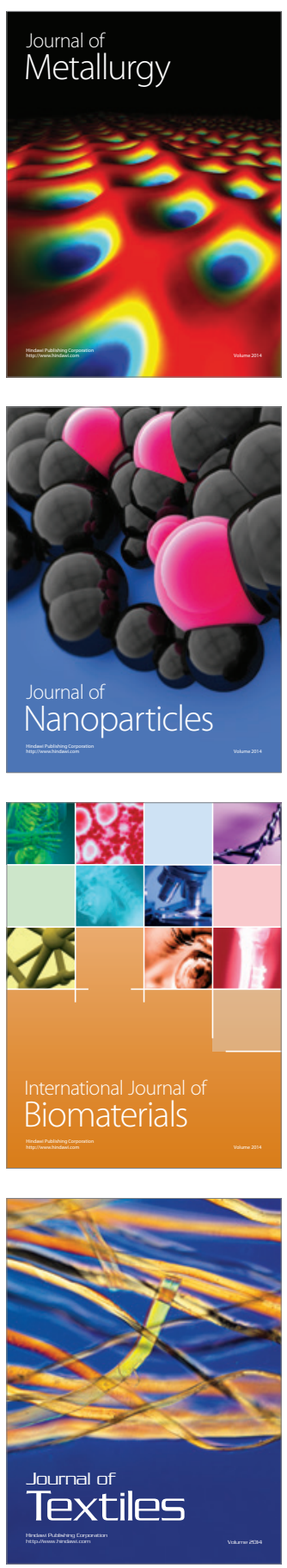